\title{
Methyl ferulic acid exerts anti-apoptotic effects on L-02 cells via the ROS-mediated signaling pathway
}

\author{
LI LI $^{1^{*}}$, YUJUAN ZHONG ${ }^{1 *}$, ZUHENG MA $^{2}$, CHENGFANG YANG $^{1}$, HANNING WEI $^{1}$, \\ LI CHEN $^{1}$, CHEN LI ${ }^{1}$, DAN WU ${ }^{1}$, MING ZHI RONG ${ }^{1}$ and YONGWEN LI ${ }^{1}$ \\ ${ }^{1}$ College of Pharmacy, Guilin Medical University, Guilin, Guangxi 541004, P.R. China; \\ ${ }^{2}$ Department of Molecular Medicine and Surgery, Karolinska Institutet, Stockholm 171 76, Sweden
}

Received December 1, 2017; Accepted April 19, 2018

DOI: $10.3892 /$ ijo.2018.4379

\begin{abstract}
The present study aimed to investigate the antiapoptotic effects of methyl ferulic acid (MFA) on L-02 cell apoptosis induced by ethanol, and to elucidate the possible underlying mechanisms. L-02 cells were examined after being soaked in ethanol $(400 \mathrm{mM})$ to allow the ethanol to permeate into the cells for $24 \mathrm{~h}$. Cell survival was measured by MTT assay. Cell apoptosis was assessed by both flow cytometry and single-stranded DNA assays. Intracellular reactive oxygen species (ROS) production was determined using the 2',7'-dichlorofluorescein-diacetate dye. The protein expression levels of p38, p-p38, JNK, p-JNK, NADPH oxidase 4 (NOX4), p22, Bax and Bcl-2 were measured by western blot analysis. The mRNA expression levels of NOX4 and p22 were measured by RT-PCR. It was identified that MFA markedly suppressed the ethanol-induced apoptosis and necrosis of L-02 cells. In addition, MFA decreased the expression levels of superoxide dismutase, catalase and phospholipid hydroperoxide gluthione peroxidase, and downregulated the levels of $\mathrm{Bax} / \mathrm{Bcl}-2$ and the cleaved forms of caspase- 3 in a dose- and time-dependent manner. This indicated that MFA attenuated the apoptosis of L-02 cells. MFA also decreased the elevated mRNA and protein expression levels of Nox4 and p22 $2^{\text {phox }}$, and the production of intracellular ROS triggered by ethanol. Further analysis demonstrated that MFA significantly attenuated the phosphorylation of JNK and $\mathrm{p} 38$, which are major components of the mitogen-activated protein kinase (MAPK) pathways. On the whole, the findings of this study demonstrated that MFA attenuated the apoptotic cell death of L- 02 cells by reducing the generation of ROS and inactivating the MAPK pathways.
\end{abstract}

Correspondence to: Dr Yongwen Li, College of Pharmacy, Guilin Medical University, Guilin, Guangxi 541004, P.R. China

E-mail: liyongwen99@163.com

*Contributed equally

Key words: ethanol, methyl ferulic acid, L-02 cells, apoptosis, reactive oxygen species, NADPH, mitogen-activated protein kinase

\section{Introduction}

Excessive alcohol consumption triggers a variety of liver disorders, ranging from simple steatosis to severe forms of liver injury, including fatty liver, steatohepatitis, liver fibrosis, cirrhosis and even liver cancer (1). Alcoholic liver disease (ALD) is a major healthcare concern, which inflicts individuals, and society as a whole, with damaging consequences and is a significant cause of economic burden worldwide $(2,3)$. The elucidation of the detailed mechanisms responsible for the development of ALD is important in order to determine an effective treatment. Mounting evidence indicates that oxidative stress plays a key role in ALD. Ethanol-induced oxidative stress directly influences the elevated production of reactive oxygen species (ROS) and increases lipid peroxidation and damage to the antioxidant system, which leads to cell apoptosis and necrosis $(4,5)$. It was recently reported that hepatocyte cell death via apoptosis and necrosis may be a critical process in ALD (6). An increasing number of studies have noted that oxidative stress and superfluous intracellular ROS production induced by ethanol and its metabolites exert a pivotal effect on ethanol-induced cellular apoptosis $(7,8)$, and suggested that apoptosis is mainly induced via the Fas- and mitochondria-mediated pathway (9).

NADPH oxidase 4 (NOX4), is expressed particularly in hepatocytes and hepatic stellate cells (HSCs), and is therefore an important source of ROS in signal transduction, playing a vital role in the physiological and pathological processes of ALD $(5,10)$. It is a reasonable hypothesis that ROS derived from NOX4 on the membrane may be associated with Fas activation (11). Relatively high levels of intracellular ROS induce redox imbalance, causing cell apoptosis via the mitogen-activated protein kinase (MAPK) signaling pathway (12).

It is known that MAPK determines the fate of various cells, and that p38 MAPK and JNK may positively influence the mitochondrial pathways that lead to the apoptosis of ethanol-exposed SK-Hepl cells, suggesting an interaction between apoptosis and MAPK signaling systems (13). L-02 is a new cell line established by the Shanghai Biochemical Institute of Chinese Academy of Sciences and was selected for use in a previous study (14); this cell line was selected for the present study as these cells have alcohol dehydrogenase (ADH) activity (15). Therefore, the results may be more 
exact, compared with cancerous hepatocytes, such as HepG2 or Hep3B.

Methyl ferulic acid (MFA) is a monomer extracted and purified from Securidaca inappendiculata Hassk. which has been traditionally used in the treatment of acute or chronic hepatitis and which has been shown to exert some inhibitory effects against HBsAg $(16,17)$. However, its anti-apoptotic effects and its distinct mechanisms of action have yet to be elucidated. Thus, in the present study, we aimed to investigate the possible mechanisms responsible for the anti-apoptotic effects of MFA against the ethanol-induced apoptosis of L-02 cells.

\section{Materials and methods}

Drug and reagents. MFA (3,4-dimethoxycinnamic acid) at $>98 \%$ purity and all other reagents (unless otherwise indicated) were obtained from Sigma-Aldrich; Merck KGaA (Darmstadt, Germany). Ethanol was purchased from JiuYi Chemical Factory (Shanghai, China).

Cells and cell culture. L-02, a normal human hepatic cell line (Chinese Academy of Sciences, Shanghai, China), was cultured in DMEM (Invitrogen; Thermo Fisher Scientific, Inc., Waltham, MA, USA) containing $10 \%$ (v/v) fetal bovine serum and antibiotics (100 U/ml penicillin and $100 \mu \mathrm{g} / \mathrm{ml}$ streptomycin) (both from HyClone; GE Healthcare Life Sciences, Little Chalfont, UK) and maintained in a humidified atmosphere of $5 \% \mathrm{CO}_{2}$ and $95 \%$ air at $37^{\circ} \mathrm{C}$.

Cells between generations 3 and 5 were used in the experiments. The L-02 cells were treated under the following conditions unless otherwise stated: Following $12 \mathrm{~h}$ of preincubation in serum-free DMEM, MFA $(25,50$ and $100 \mu \mathrm{M})$ was added to the cultures for pretreatment. Following incubation with MFA for $1 \mathrm{~h}$, ethanol (400 $\mathrm{mM})$ was added to DMEM and the cells incubated for a further $24 \mathrm{~h}$.

Cell viability assay. Cell viability was ascertained by MTT assay. First, the cells were seeded into 96-well plates ( $5 \times 10^{4}$ cells/well) $24 \mathrm{~h}$ prior to treatment. The cells were then treated with MFA at various concentrations $(25,50,100,250$, $500,1,000$ and $2,000 \mu \mathrm{M}$ for 24,48 or $72 \mathrm{~h}$, respectively) prior to being incubated with a working solution of MTT $(5 \mathrm{mg} / \mathrm{ml})$ at $37^{\circ} \mathrm{C}$ for $4 \mathrm{~h}$. Following treatment with $150 \mu \mathrm{l}$ of DMSO to dissolve the crystals, the cells were placed in a microplate reader (Mutiskan FC; Thermo Fisher Scientific, Inc.) to measure the absorbance at $570 \mathrm{~nm}$. All experiments were conducted with strict sterile precautions and repeated $\geq 3$ times.

Apoptosis detection by flow cytometry. To further examined whether MFA could L-02 cell apoptosis induced by ethanol, apoptosis was quantified using an Annexin V-fluorescein isothiocyanate (FITC) Apoptosis Detection kit (Roche Diagnostics GmbH, Mannheim, Germany) in accordance with the manufacturer's instructions. Briefly, following treatment with MFA for $24 \mathrm{~h}$ at various concentrations as mentioned above, the cells were harvested and washed twice with cold PBS. Following centrifugation $\left(500 \mathrm{x} \mathrm{g}, 5 \mathrm{~min}, 25^{\circ} \mathrm{C}\right)$, the cells were stained with Annexin V-FITC and PI, and then analyzed by flow cytometry (flow cytometer; BD Biosciences, San Jose, CA, USA).

Measurement of aspartate aminotransferase (AST), glutathione peroxidase (GSH-Px), superoxide dismutase (SOD) and catalase (CAT) levels. Firstly $3 \times 10^{6}$ cells were cultured in a dish (diameter, $10 \mathrm{~cm}$ ) for $24 \mathrm{~h}$, and the DMEM was then discarded. Secondly, the MFA (100, 50 and $25 \mu \mathrm{m})$ group was pre-cultured with MFA for $1 \mathrm{~h}$, and the cells in the model group and MAF group were then supplemented with $400 \mathrm{mM}$ ethanol and culture for $24 \mathrm{~h}$. Thirdly, the supernatant from the cultured cells was collected and used immediately for the assay of AST using the aspartate aminotransferase assay kit (C010-2; Nanjing Jiancheng Bio Co., Nanjing, China) according to the manufacturer's instructions. The cells were then split and the active protein was extracted using the One Step Animal Cell Active Protein Extraction kit (C500022; Sangon Biotech Co., Ltd., Shanghai, China). The antioxidant enzyme (SOD and CAT) and GSH-Px activities were then evaluated using different detection kits respectively according to the manufacturer's instructions as follows: The superoxide dismutase assay kit (A001-3), catalase assay kit (A007-2) and glutathione peroxidase (GSH-PX) assay kit (A005) (all from Nanjing Jiancheng Bio Co.).

Measurement of ROS generation. ROS generation was evaluated with an intracellular ROS Assay kit in accordance to the manufacturer's instructions (Cell Biolabs Inc., San Diego, CA, USA). DCFH-DA itself does not fluoresce, but can freely cross the cell membrane and enter the cell to be hydrolyzed to DCFH by esterase in the cell. DCFH cannot permeate the cell membrane, and thus the probe is easily loaded into the cell. ROS in the cell can oxidize the non-fluorescent DCFH to produce the fluorescent DCF, and the amount of DCF fluorescence can be used to identify the level of ROS in the cells. The ROS level was verified with a Tecan Model infinite M200 PRO Microplate reader (Tecan Group, Ltd., Mannedorf, Switzerland) at an emission wavelength and excitation wavelength of 523 and $502 \mathrm{~nm}$, respectively.

$R N A$ extraction and reverse transcription $(R T)-P C R$. Following the manufacturer's instructions, total RNA was isolated from the cells with the total RNA isolation kit (Tripure Reagent; Mai Bio Co., Shanghai, China), and then reverse transcribed into cDNA with a cDNA synthesis kit (TIANScript cDNA; Tiangen Biotech Co., Ltd., Beijing, China) in accordance with the manufacturer's instructions. Target genes were amplified by the MJ ptc-200 PCR amplification system (MJ Research, Inc., Waltham, MA, USA) with a RT-PCR kit (2X Taq PCR Master Mix; Aidlab Biotechnologies Co., Ltd., Beijing, China) according to the manufacturer's instructions. The specific primers for the target genes, GAPDH and $\beta$-actin, were synthesized by Sangon Biotech Co., Ltd. and are listed in Table I. $\beta$-actin was used as an internal control. The parameters of the reaction were based on those in our previous study (17). The PCR products were identified using $1.5 \%$ agarose gel electrophoresis, and the optical density of the target gene bands in each sample was calculated using the ChemiDoc imaging system with adjustment through $\beta$-actin correction to finally obtain the relative expression of the target genes in each sample. 
Table I. Sequences of primers used for the determination of NOX4, p22 phox, Bax, Bcl-2 and $\beta$-actin gene expression.

\begin{tabular}{|c|c|c|c|}
\hline Gene & Oligonucleotide primer sequence & Annealing temperature & Number of cycles \\
\hline NOX4 (136 bp) & $\begin{array}{l}\text { Forward: 5'-TGTGCCGAACACTCTTGGC-3' } \\
\text { Reverse: 5'-ATATGCACGCCTGAGAAAATA-3' }\end{array}$ & $58^{\circ} \mathrm{C}$ & 35 \\
\hline p22 $2^{\text {phox }}(103 \mathrm{bp})$ & $\begin{array}{l}\text { Forward: 5'-TATTGTTGCAGGAGTGCTCA-3' } \\
\text { Reverse: 5'-CACAGCGGTCAGGTACTTCT-3' }\end{array}$ & $58^{\circ} \mathrm{C}$ & 35 \\
\hline Bax (155 bp) & $\begin{array}{l}\text { Forward: 5'-CCCGAGAGGTCTTTTTCCGAG-3' } \\
\text { Reverse: 5'-CCAGCCCATGATGGTTCTGAT-3' }\end{array}$ & $53^{\circ} \mathrm{C}$ & 35 \\
\hline Bcl-2 (89 bp) & $\begin{array}{l}\text { Forward: 5'-GGTGGGGTCATGTGTGTGG-3' } \\
\text { Reverse: 5'-CGGTTCAGGTACTCAGTCATCC-3' }\end{array}$ & $55^{\circ} \mathrm{C}$ & 35 \\
\hline$\beta$-actin (199 bp) & $\begin{array}{l}\text { Forward: 5'-GGACTCCTATGTGGGTGACGA-3' } \\
\text { Reverse: 5'-ACGGTTGGCCTTAGGGTTCA-3' }\end{array}$ & $56^{\circ} \mathrm{C}$ & 35 \\
\hline
\end{tabular}

Western blot analysis. Total proteins were extracted from the cells and the concentration was analyzed with a BCA protein concentration assay kit (Beyotime Institute of Biotechnology, Haimen, China). Sample proteins were separated by electrophoresis by a $12 \%$ SDS-PAGE separating gel with a Bio-Rad electrophoresis system (Bio-Rad Laboratories, Inc., Hercules, CA, USA). Equivalent amounts $(50 \mu \mathrm{g})$ of protein were then transferred onto Pure Nitrocellulose Blotting membranes and blocked with $5 \%$ fat-free milk, the proteins were then incubated with the primary antibodies [anti-NOX4 (1:1,000; ab13303), Bcl-2 (1:1,000; ab59348) (both from Abcam, Cambridge, UK), caspase-3 (1:1,000; 9662S; Cell Signaling Technology Inc., Danvers, MA, USA), cleaved caspase-3 (1:500; D260009; Sangon Biotech Co., Ltd.), Bax (1:1,000; ab53154), JNK1/2 (1:1,000; ab124956), p-JNK1/2 (1:1,000; ab207477) (all from Abcam), anti-p22 ${ }^{\text {phox }}$ rabbit antibody (1:500; Bioworld Technology, Inc., Nanjing, China), anti-p-p38 MAPK (1:1,000; ab4822) and anti-p38 MAPK antibodies (1:1,000; ab170099) (both from Abcam)] overnight at $4^{\circ} \mathrm{C}$. The membranes were then incubated with the corresponding horseradish peroxidase-conjugated secondary antibodies (1:50,000; TA140003; goat anti-rabbit IgG; OriGene Technologies, Inc., Beijing, China) at room temperature for $1 \mathrm{~h}$. The qualitative and quantitative analysis of the blots were estimated with Molecular Imager Chemi Doc XRS (Bio-Rad Laboratories, Inc.) by enhanced chemiluminescence (E002-100; 7Sea Pharmatech Co., Ltd., Shanghai, China) and the JS-780 automatic gel imaging analysis system. $\beta$-actin (1:1,000; C640018; Sangon Biotech Co., Ltd.) was used as the internal control.

NOX4 overexpression. The L-02 cells were electroporated with the P5 primary cell Nucleofector ${ }^{\mathrm{TM}}$ kit (Lonza, Basel, Switzerland). For each transfection with NOX4-cDNA (provided by Shanghai Genechem Co., Ltd., Shanghai, China), $18 \mu \mathrm{l}$ supplemented P5 primary cell solution were added to the prepared mixed solution of $3 \mu \mathrm{g}$ of NOX4-cDNA dissolved with $82 \mu \mathrm{l}$ Nucleofector. Approximately $10^{7}-10^{8}$ cells were resuspended in $100 \mu \mathrm{l}$ cDNA plus P5 primary cell solution and electroporation conducted in a 4D-Nucleofector $\mathrm{X}$ kit $\mathrm{L}$ cuvette. The cells were then transferred to 6-well plates containing $2.5 \mathrm{ml}$ warm complete medium in a humidified atmosphere of $5 \% \mathrm{CO}_{2}$ at $37^{\circ} \mathrm{C}$. The medium was changed after $24 \mathrm{~h}$ of incubation.
Transfection of small interfering (si)RNA. siRNA directed against NOX4 (NOX4-siRNA) and negative control siRNA (NC-siRNA) were obtained from Gene Pharma (Shanghai, China). The NOX4- or NC-siRNA was transfected into the L02 cells using Lipofectamine ${ }^{\circledR}$ (Invitrogen; Thermo Fisher Scientific, Inc.) in accordance with the manufacturer's instructions. Briefly, the cells were seeded in 6-well plates at a density of $2 \times 10^{5}$ cells/well in $2 \mathrm{ml}$ of complete DMEM. When the cells grew to $\sim 70 \%$ confluence transfection with siRNA commenced as follows: A total of $100 \mathrm{pmol}$ of siRNA was mixed with $2 \mu \mathrm{l}$ of Lipofectamine ${ }^{\circledR}$ in each well, and $500 \mu \mathrm{l}$ of antibiotic- and serum-free DMEM medium were then added. The cells were incubated with the transfection mixture for $6 \mathrm{~h}$. At the final stage of incubation, $1.5 \mathrm{ml}$ of antibiotic-free complete medium was replenished and the cells were incubated for a further $18 \mathrm{~h}$. Following exposure to ethanol for $24 \mathrm{~h}$, the cells were harvested and the NOX4 protein and mRNA expression levels were evaluated by western blot analysis and RT-PCR, respectively.

Statistical analysis. The results are expressed as the means \pm standard deviation. All experimental data were analyzed using SPSS software version 17.0 (SPSS, Inc., Chicago, IL, USA). One-way analysis of variance was used to determine significant differences among groups with the Student-Newman-Keuls (SNK-q) post hoc test. $\mathrm{P}<0.05$ was considered to indicate a statistically significant difference.

\section{Results}

Effect of MFA on the viability of L-O2 cells. The cytotoxic effects of MFA on the cells were evaluated by MTT assay. The cells were treated with various concentrations of MFA $(25,50,100,250,500,1,000$ and $2,000 \mu \mathrm{M})$ for 24,48 or $72 \mathrm{~h}$, respectively. The percentages of cell growth inhibition for each treatment group were calculated by adjusting the untreated control group to $100 \%$. Only $15 \%$ cell growth inhibition was observed at a MFA concentration $<250 \mu \mathrm{M}$, even after $72 \mathrm{~h}$ of treatment (Fig. 1A).

To examine the effects of ethanol on the viability of cells, the L-02 cells were cultured in DMEM with or without (as a control) ethanol. A pre-experimental experiment was 
conducted in which viability for $3,6,12,24$ and 48 h was estimated at various concentrations of ethanol $(100,200,300$, $400,500,600$ and $700 \mathrm{mM}$ ). The results demonstrated that the cell inhibition rate of $400 \mathrm{mM}$ ethanol was close to $50 \%$ at $24 \mathrm{~h}$ (data not shown). It was thus determined that $400 \mathrm{mM}$ ethanol was the appropriate concentration for inducing L-02 cell apoptosis.

In order to obtain the optimal experimental conditions, the concentrations of $1,2.5,5,10,25,50,100$ and $200 \mu \mathrm{M}$ of MFA and $400 \mathrm{mM}$ ethanol were used for the preliminary experiment (Fig. 1B). The concentrations of 100,50 and $25 \mu \mathrm{M}$ of MFA and $400 \mathrm{mM}$ of ethanol were selected for use in further experiments as they produced significant changes in the viability of the cells compared with the control.

MFA attenuates the ethanol-induced apoptosis of ethanolexposed L-O2 cells. In order to determine whether MFA mediates the ethanol-induced apoptosis or necrosis of L-02 cells, Annexin V-PI flow cytometric analysis, which can differentiate between apoptotic and necrotic cells, was performed. MFA treatment caused a significant decrease in the number of Annexin V-positive L-02 cells in a concentration-dependent manner. The results demonstrated that the apoptotic rate in the group exposed to ethanol was significantly increased by $89 \%(\mathrm{P}<0.01)$ and the apoptotic rate in the MFA group was significantly lower compared with that in the ethanol group $(\mathrm{P}<0.01)$. The level of apoptosis of L-02 cells decreased by 29.1, 20.7 and $15.3 \%$ following treatment with MFA at 100, 50 and $25 \mu \mathrm{M}$ for $24 \mathrm{~h}$, respectively. These results suggested that MFA attenuates the ethanol-induced apoptosis of L-02 cells (Fig. 2A).

To further evaluate the anti-apoptotic effects of MFA, the effects of MFA on apoptosis-associated proteins that serve as biomarkers of cell apoptosis (Bax, Bcl-2, cleaved caspase-3 and caspase-3) were also examined in vitro. The results from western blot analysis (Fig. 2B) demonstrated that ethanol exposure mainly increased Bax, caspase- 3 and cleaved caspase- 3 protein expression, but decreased $\mathrm{Bcl}-2$ protein expression compared with the control. Although at the mRNA level, ethanol was also found to increase both the level of Bax and Bcl-2 expression compared with the control (Fig. 2C), the protein level of $\mathrm{Bcl}-2$ decreased with ethanol treatment compared to that of the control. Western blot analysis also revealed that the alcohol-exposed L-02 cells exhibited an elevated $\mathrm{Bax} / \mathrm{Bcl}-2$ protein expression $(\mathrm{P}<0.01)$. In addition, the protein level of anti-apoptotic $\mathrm{Bcl}-2$ was increased following treatment with MFA in the L-02 cells compared with the control group $(\mathrm{P}<0.01)$, while the levels of the apoptotic proteins, caspase- 3 and Bax, were decreased $(\mathrm{P}<0.01)$. Taken together, these findings suggest that MFA attenuates the ethanol-induced apoptosis of L-02 cells in a dose-dependent manner by regulating the levels of apoptotic proteins. The effect of $100 \mu \mathrm{M}$ MFA dose is particularly prominent.

MFA affects the generation of AST, GSH-Px, SOD and CAT in ethanol-exposed $L-02$ cells. It has been reported that ethanolinduced cell death is partly mediated by oxidative stress (13). To alleviate the cumulative burden of oxidative stress, cells generally utilize antioxidant defense systems to eliminate ROS. SOD, GSH-Px and CAT are the first line of defense
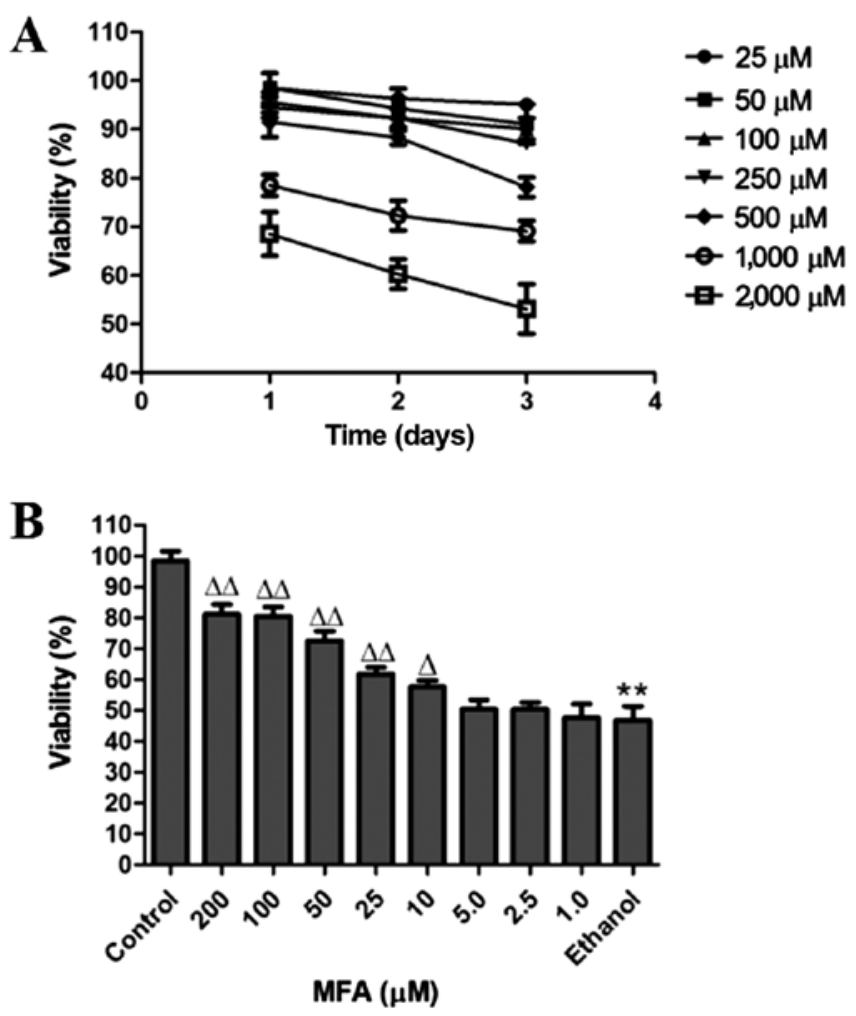

Figure 1. Effects of methyl ferulic acid (MFA) on ethanol-induced L-02 cell viability. L-02 cell viability was examined by MTT assay following treatment with (A) MFA $(25,50,100,250,500,1,000$ and 2,000 $\mu \mathrm{M})$; and (B) MFA $(1.0,2.5,5,10,25,50,100$ and $200 \mu \mathrm{M})$ with or without ethanol $(400 \mathrm{mM})$ as described in the Materials and methods. Data are expressed as the means $\pm \mathrm{SD}, \mathrm{n}=6 .{ }^{* *} \mathrm{P}<0.01$ vs. the control group; ${ }^{\triangle} \mathrm{P}<0.05$ and ${ }^{\triangle \triangle} \mathrm{P}<0.01$ vs. the ethanol group.

against oxidative stress and can block free radical formation and prevent the cells from oxidative damage by ROS (19). SOD is able to convert the superoxide radical into $\mathrm{H}_{2} \mathrm{O}_{2}$, which can be broken down to $\mathrm{O}_{2}$ by CAT and GSH-Px (20). In the present study, to determine whether the protective effects of MFA against ethanol-induced injury are mediated via antioxidant enzymes, the activities of antioxidant enzymes in L-02 cells with or without pretreatment with MFA were investigated. First the L-02 cells were treated with MFA in the presence or absence of ethanol for $24 \mathrm{~h}$, and the activities of AST in the culture medium and the levels of GSH-Px, CAT and SOD in the cell lysates were then detected. As shown in Fig. 3A, the activities of AST in the ethanol-exposed group were significantly increased by $125 \%$ compared with those of the control group $(\mathrm{P}<0.01)$. However, treatment with MFA $(100,50$ and $25 \mu \mathrm{M})$ significantly inhibited the ethanolinduced elevation of AST activities by 65.5, 52.8 and 39.7\%, respectively. In addition, MFA significantly increased the levels of GSH-Px, CAT and SOD levels compared with those in the ethanol-exposed cells (Fig. 3B-D). MFA (100, 50 and $25 \mu \mathrm{M}$ ) increased the GSH-Px levels by 230,170 and $110 \%$ compared with the ethanol-exposed cells, respectively. MFA $(100,50$ and $25 \mu \mathrm{M})$ also increased the CAT levels by 556 , 412.1 and $223.1 \%$, respectively compared with those in the ethanol-exposed cells, and MFA $(100,50$ and $25 \mu \mathrm{M})$ also elevated the SOD levels by $631.2,432.3$ and $337.0 \%$, respectively compared with those in the ethanol-exposed cells. 
A

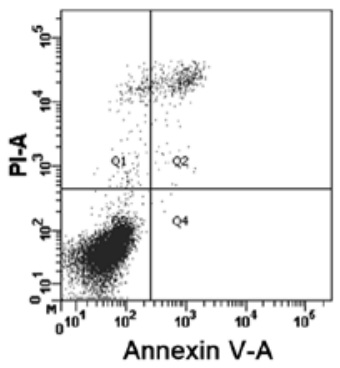

A-a

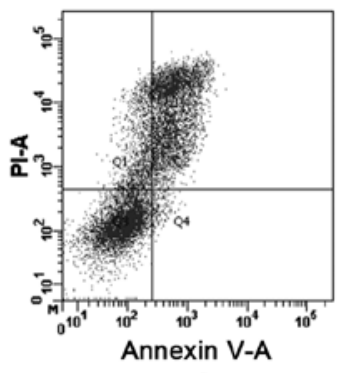

A-b

B
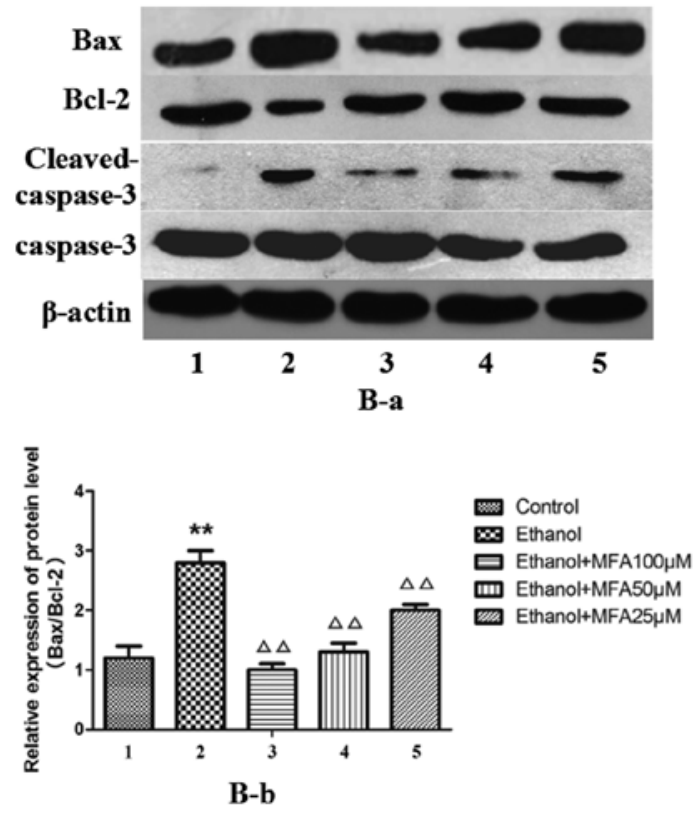

C

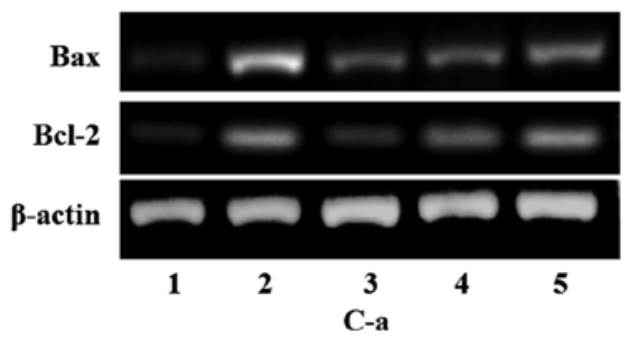

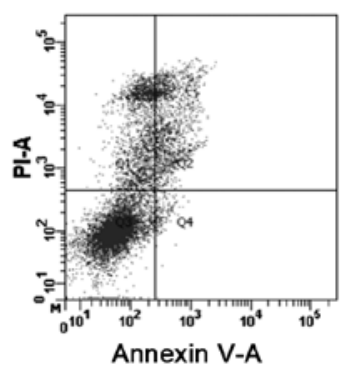

A-c

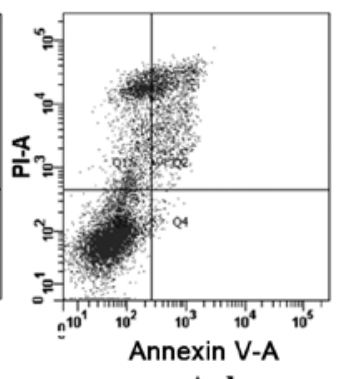

A-d

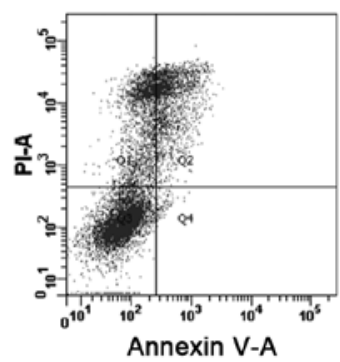

A-e

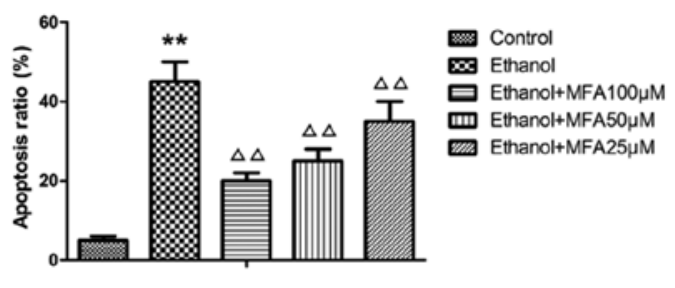

A-f
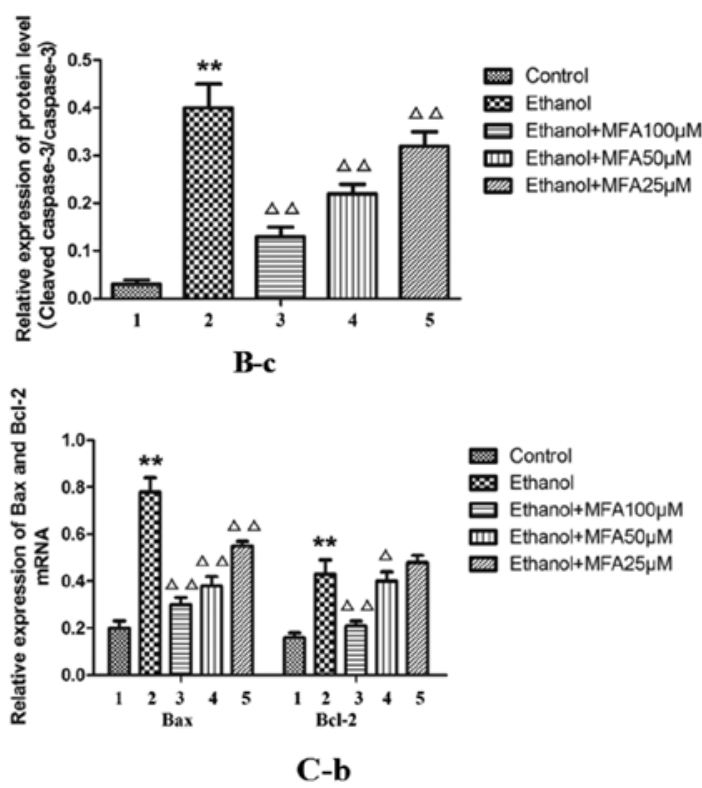

Figure 2. Effects of methyl ferulic acid (MFA) on ethanol-induced L-02 cell apoptosis. (A) Cell apoptosis was influenced by pre-incubation with MFA (100, 50 and $25 \mu \mathrm{M}$ ) in ethanol-exposed L-02 cells; (B) Protein expression levels of Bax, Bcl-2, cleaved caspase-3, caspase-3 and $\beta$-actin were detected by western blot analysis after the L-02 cells were treated with MFA (100,50 and $25 \mu \mathrm{M})$ in the absence/presence of ethanol (400 mM) for $24 \mathrm{~h}$; (C) The mRNA levels of Bax and Bcl-2 ere normalized to $\beta$-actin. Data are presented as the means $\pm \mathrm{SD}, \mathrm{n}=3$. ${ }^{* *} \mathrm{P}<0.01$ vs. the control group; ${ }^{\wedge} \mathrm{P}<0.05$ and ${ }^{\triangle} \mathrm{P}<0.01$ vs. the ethanol group. Lanes and bars are numbered as follows: 1, control; 2, ethanol; 3, ethanol + MFA $100 \mu \mathrm{M} ; 4$, ethanol + MFA $50 \mu \mathrm{M} ; 5$, ethanol + MFA $25 \mu \mathrm{M}$.

Notably, treatment with MFA significantly reduced ethanolinduced oxidative stress, as demonstrated by the reduction in the ROS levels when compared with the ethanol-exposed cells (Fig. 3E and F).

The anti-apoptotic effects of MFA are mediated via ROS generation. In recent years, a number of studies have demonstrated that oxidative stress can cause cellular apoptosis $(6,13)$. ROS production increases in ethanol-stimulated L- 02 cells and leads to apoptosis (14). Therefore, the present study investigated whether the inhibitory effects of MFA on the ethanol-induced apoptosis of L-02 cells were associated with the accumulation of ROS. First, the ROS levels in ethanol-exposed L-02 cells were estimated by determining the oxidative conversion of non-fluorescent DCFH-DA to fluorescent DCF. Consistent with the findings of a previous study (17), the exposure of L-02 cells to ethanol triggered the generation of ROS and apoptosis. The results of the present study demonstrated that ethanol triggered ROS production in the L-02 cells; the level of ROS was significantly increased by about 2 times compared with that of the control group $(\mathrm{P}<0.01)$ (Fig. $3 \mathrm{E}$ and $\mathrm{F})$. Following treatment with MFA $(100,50$ and $25 \mu \mathrm{M})$, the levels of ROS generation levels were partly blocked; compared with the ethanol group, the levels of ROS were reduced in all the 3 MFA treatment (all 3 concentrations $)(\mathrm{P}<0.01)$.

As mentioned above, the exposure of the L-02 cells to ethanol induced the production of ROS and apoptosis. MFA treatment successfully reduced ethanol-induced ROS 
A

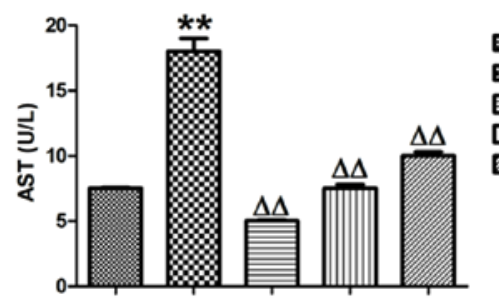

C

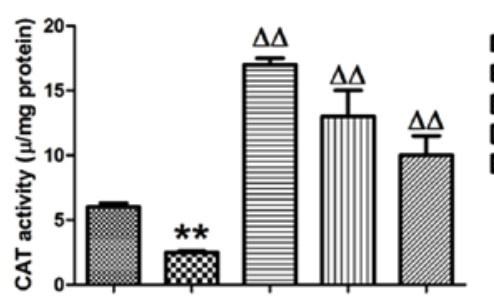

$\mathbf{E}$

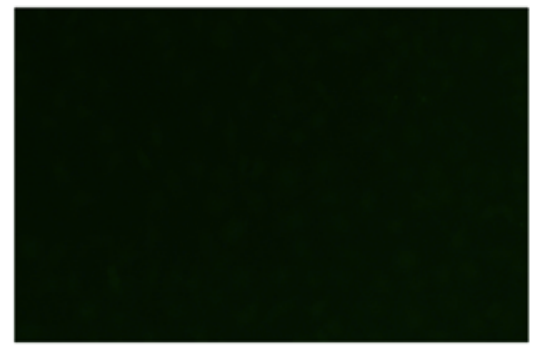

a

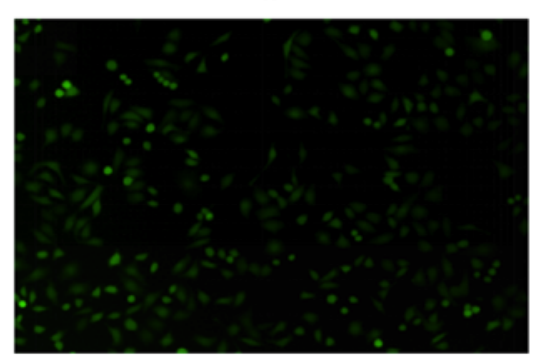

c

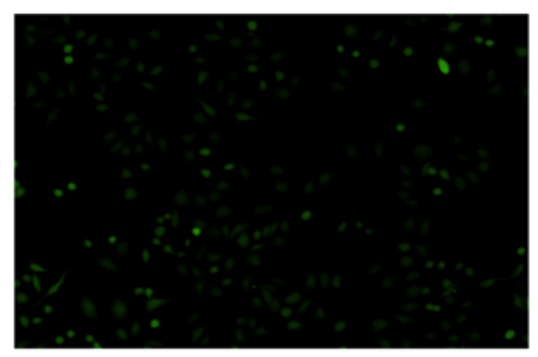

e

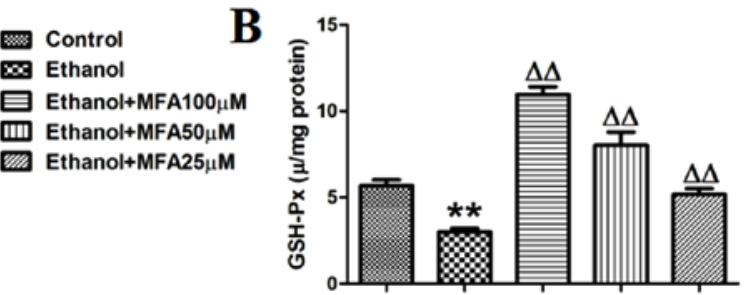

D
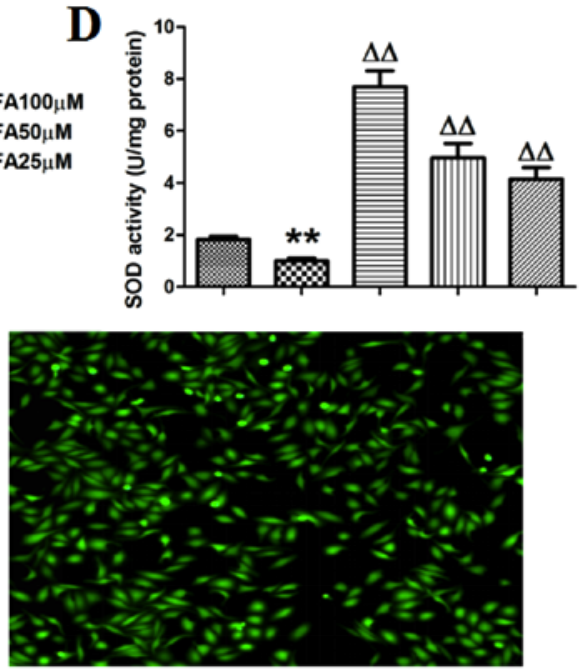

b

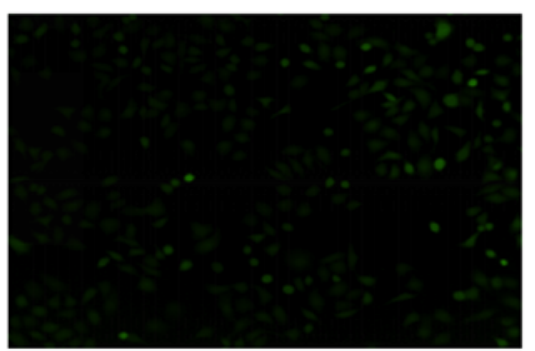

d

$\mathbf{F}$

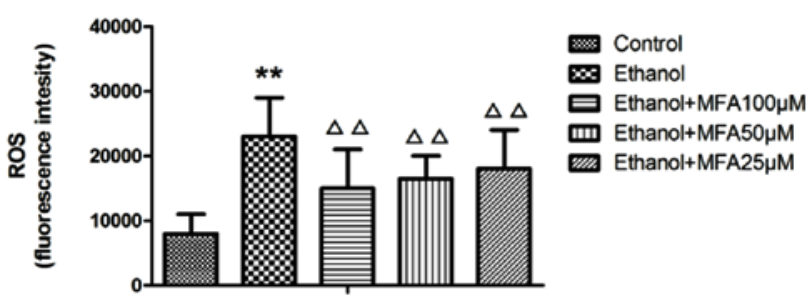

Figure 3. Protective effects of methyl ferulic acid (MFA) against ethanol-induced oxidative injury. L-02 cells were treated with MFA (100, 50 and $25 \mu \mathrm{M})$ in the absence/presence of ethanol (400 mM) for $24 \mathrm{~h}$. (A) Aspartate aminotransferase (AST) in the culture medium, (B) glutathione peroxidase (GSH-Px), (C) catalase (CAT) and (D) superoxide dismutase (SOD) in the cell lysates, were measured using commercial kits. (E) Preventive effects of MFA against ethanol-induced reactive oxygen species (ROS) generation. (F) The fluroscence intensity of ROS in each group. Data are expressed as the means \pm SEM, $\mathrm{n}=3$. ${ }^{* * *} \mathrm{P}<0.01$ vs. the control group; ${ }^{\triangle} \mathrm{P}<0.01$ vs. the ethanol group.

generation (Fig. 3E and F) and attenuated the ethanol-induced apoptosis of L-02 cells (Fig. 2A). These results suggested that ROS generation acts upstream of apoptosis in ethanol-exposed L-02 cells. A similar association was also confirmed in two other hepatoma carcinoma cell lines (SK-HEP-1 and HepG2; data not shown). Collectively, these findings suggested that the signaling pathway through which ethanol induces the apoptosis of L-02 cells involves ROS as a second messenger. MFA reverses ethanol-induced ROS production and apoptosis.
MFA inhibits the expression levels of Nox4 and p22 phox in L-O2 cells. Recently, studies have emphasized NADPH oxidases (NOX) as a key source of ROS. NOX4 and its subunit p22 $2^{\text {phox }}$ are highly expressed in hepatocytes and HSCs $(7,18)$. In this study, to further understand the mechanisms underlying the MFA-induced reduction in ROS generation, the effects of MFA on NOX4, one of the major sources of ROS generation found in cells, were assessed. NOX4 appears to be the most abundant isoform of NOXs expressed in the liver (18); 
A

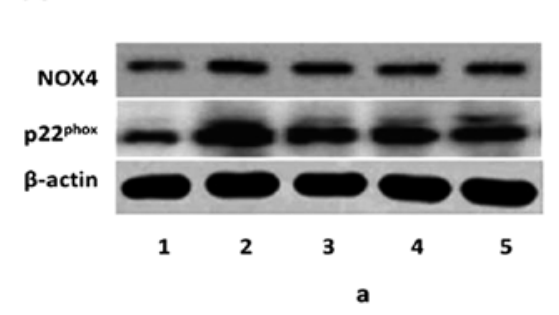

B
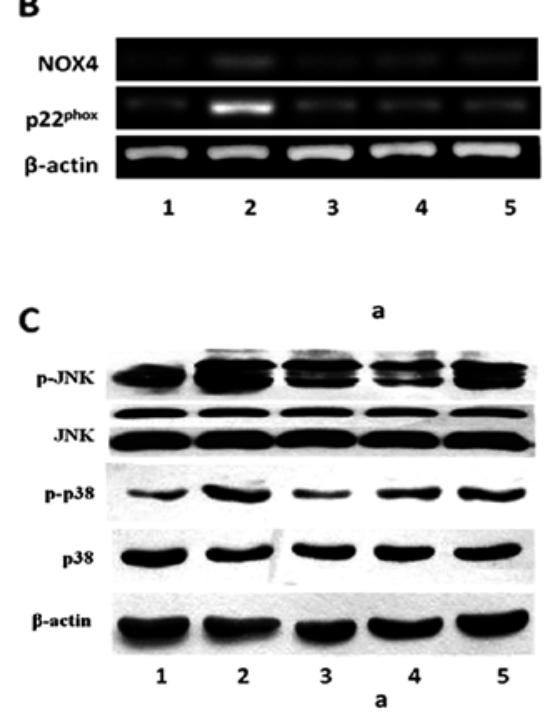

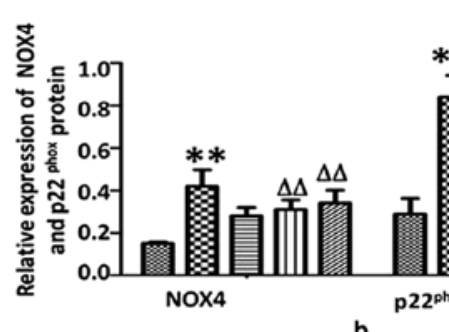

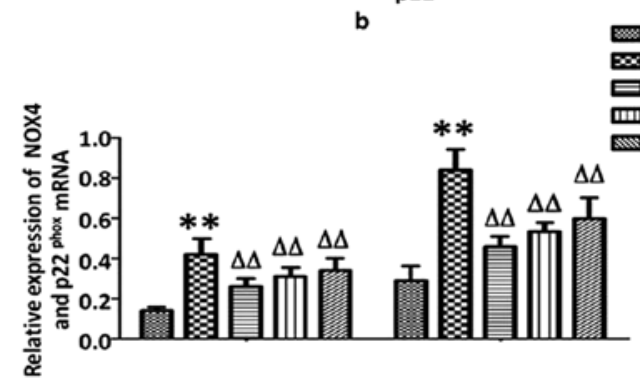

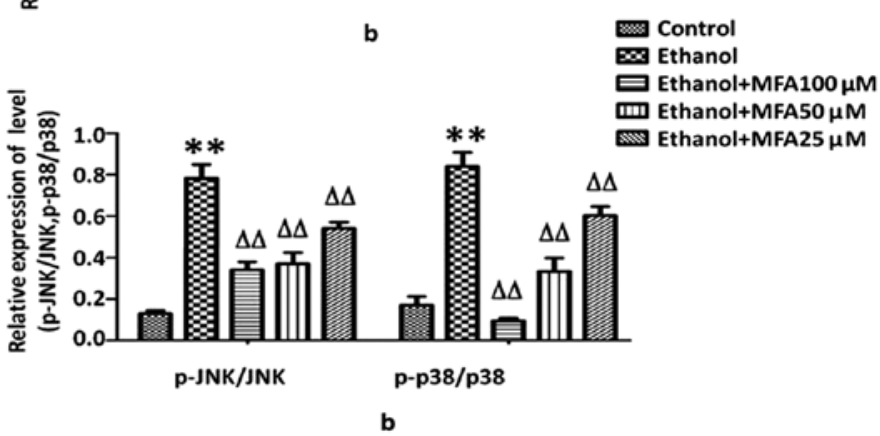

Figure 4. Expression of NOX4 signaling components mediated by methyl ferulic acid (MFA) in ethanol-exposed L-02 cells. L-02 cells were treated with MFA (25, 50 and $100 \mu \mathrm{M}$ ) for $1 \mathrm{~h}$ prior to incubation with $400 \mathrm{mM}$ ethanol. (A) Protein expression levels of NOX4 and p22 ${ }^{\text {phox }}$ were normalized to $\beta$-actin. (B) The mRNA levels of NOX4 and p22 $2^{\text {phox }}$ were normalized to $\beta$-actin. (C) Effects of MFA on the MAPK pathways in L- 02 cells. ${ }^{* *} \mathrm{P}<0.01$ vs. the control group; ${ }^{\triangle} \triangle \mathrm{P}<0.01$ vs. the ethanol group. Lanes and bars are labeled as follows: 1, control; 2, ethanol; 3, ethanol + MFA $100 \mu \mathrm{M}$; 4, ethanol + MFA $50 \mu \mathrm{M} ; 5$, ethanol + MFA 25 $\mu \mathrm{M}$.

therefore, the expression levels of NOX4, as well as its regulatory subunit, $\mathrm{p} 22^{\text {phox }}$, were measured. It was identified that the protein expression of NOX4 and $22^{\text {phox }}$ was significantly increased (75.3 and $120.5 \%$, respectively) compared with the control group in response to ethanol. By contrast, treatment with MFA significantly decreased the expression of NOX4 by $56.2 \%$ and the expression of $\mathrm{p} 22^{\text {phox }}$ by $25.6 \%$, even at the low concentration of $25 \mu \mathrm{M}(\mathrm{P}<0.01)$. A dose-dependent pattern was identified (Fig. 4A). To further determine whether the downregulation of NOX4 and $\mathrm{p} 22^{\text {phox }}$ protein expression induced by MFA was due to alterations in mRNA transcription, RT-PCR was performed to analyze the mRNA levels of NOX4 and p22 $2^{\text {phox }}$. Following exposure to ethanol, the mRNA levels of NOX 4 were increased by $256.2 \%$ and those of $\mathrm{p} 22^{\text {phox }}$ were increased by $320.5 \%$ compared with the control group. Concomitant with the reduction in the protein expression induced by MFA, treatment with MFA significantly decreased the mRNA expression levels of NOX4 and p22 $2^{\text {phox }}$. MFA (100, 50 and $25 \mu \mathrm{M}$ ) decreased the mRNA levels of NOX4 by 68.8 , 56.2 and $40.6 \%(\mathrm{P}<0.01)$, respectively, compared with those of the control group. MFA $(100,50$ and $25 \mu \mathrm{M})$ decreased mRNA levels of $\mathrm{p} 22^{\text {phox }}$ by 75.3, 53.4 and $50.7 \%(\mathrm{P}<0.01)$, respectively, compared with those of the control group (Fig. 4B).

MFA treatment attenuates ethanol-induced MAPK phosphorylation in L-O2 cells. ROS has been regarded as a potent regulator of MAPK family members and subsequent cell death. To activate p38 MAPK pathway would accelerate cell apoptosis, JNKs have been considered to be involved in stimulating apoptotic signaling. Oxidative stress can switch on JNK to bring about apoptosis by receptor-initiated extrinsic and mitochondrial intrinsic apoptotic pathways. JNKs also serve an essential role in modulating the functions of pro- and antiapoptotic proteins located in the mitochondria (12).

MAPK cascades are pivotal signaling pathways involved in the regulation of normal cell proliferation and survival. Hence, the level of phosphorylated MAPKs in the presence and/or absence of MFA was measured in this study. As demonstrated in Fig. 4C, compared with the control, the phosphorylation levels of p38 MAPK and JNK were markedly increased in the L-02 cells following exposure to ethanol, and the levels of p-p38 and p-JNK increased by 50.3 and $76.2 \%$, respectively compared with the control. By contrast, compared with the ethanol-exposed group, treatment with MFA (100, 50 and $25 \mu \mathrm{M})$ effectively decreased the level of p-p38 by $70.3,46.0$ and $11.1 \%$, and the level of p-JNK by $59.3,45.0$ and $25.1 \%$, respectively, thereby exhibiting its promising activation of the p38 MAPK and JNK pathways. MFA decreased MAPK activation in a concentration-dependent manner, suggesting that MAPK inhibition by MFA can result in increased survival rates of L-02 cells (Fig. 4C).

Effects of MFA on cell viability and ROS generation in ethanol-exposed L-02 cells following transfection with NOX4 
$\mathbf{A}$
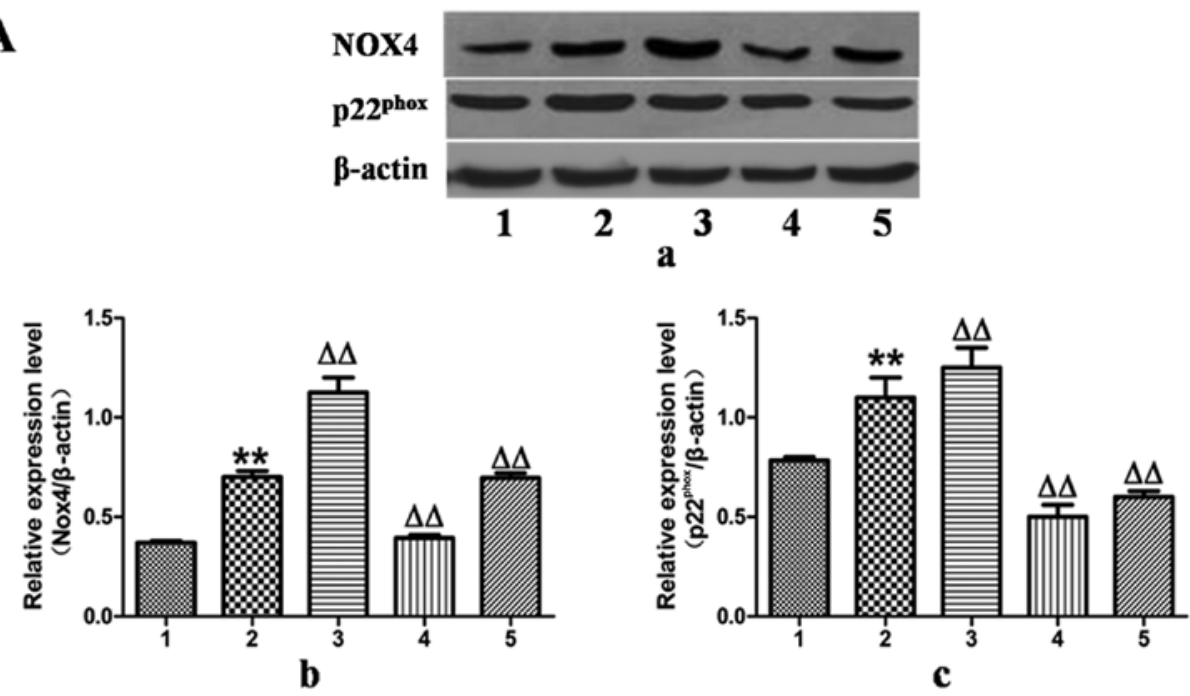

B

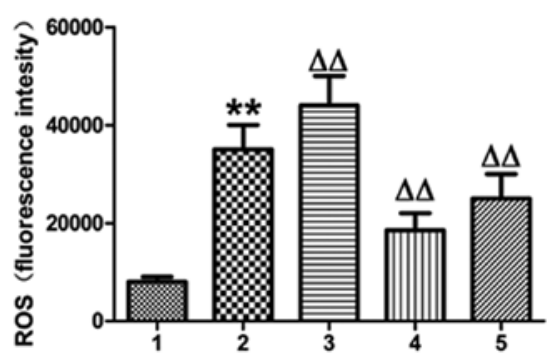

C

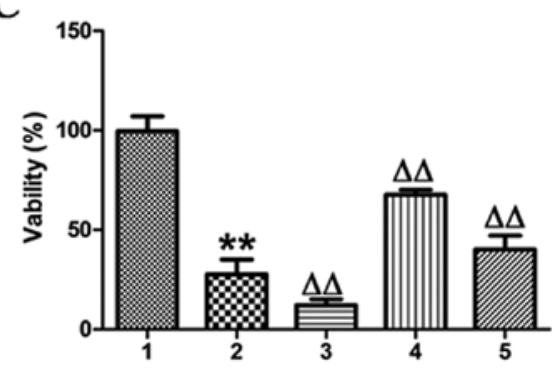

Figure 5. Effect of methyl ferulic acid (MFA) on ethanol-induced reactive oxygen species (ROS) generation in L-02 cells transfected with NOX4 overexpression. Following transfection for $24 \mathrm{~h}, \mathrm{~L}-02$ cells were treated with MFA $(25 \mu \mathrm{M})$ for $1 \mathrm{~h}$ prior to incubation with $400 \mathrm{mM}$ ethanol. (A) Representative images and protein relative expression levels of NOX4 and p22 phox in NOX4-overexpressing L-02 cells. (B) Measurement of intracellular ROS levels using DCFH-DA in various groups. (C) Cell viability was measured by MTT assay in NOX4-overexpressing L-02 cells. Data are expressed as the means \pm SD, $n=3$. ${ }^{* *} \mathrm{P}<0.01$ vs. the control group; ${ }^{\triangle} \mathrm{P}<0.01$ vs. the ethanol group. Lanes and bars are labeled as follows: 1 , control; 2 , overexpression group; 3 , overexpression group exposed to ethanol; 4, overexpression group treated with MFA; 5, overexpression group exposed to ethanol and treated with MFA.

overexpression and NOX4 siRNA. To validate the hypothesis that MFA decreased ethanol-induced ROS generation by blocking the NOX4 signaling pathway, the expression of NOX4 was upregulated by transfection of the L-02 cells with NOX4 overexpression cDNA for $24 \mathrm{~h}$, which increased the protein expression levels of NOX4 and p22 ${ }^{\text {phox }}$ by 55 and 18\%, as verified by western blot analysis (Fig. 5A). Correspondingly, ROS production increased by $25 \%$ and the cell activity decreased by $65 \%$ compared with the control group (Fig. $5 \mathrm{~B}$ and $\mathrm{C}$ ). However, these responses were effectively reversed by treatment with MFA.

In contrast to the results observed for NOX4 overexpression, the expression of NOX4 was downregulated by transfection of the L-02 cells with NOX4-siRNA for $24 \mathrm{~h}$, which reduced the protein expression levels of NOX4 and p22 phox by 67 and $34 \%$, as determined by western blot analysis (Fig. 6A). Correspondingly, ROS production was decreased by $49 \%$ and cell viability was increased by $65 \%$ compared with the ethanol-exposed group (Fig. 6B and C).

Additionally, when treatment with MFA was applied to the NOX4-overexpressing or NOX4-siRNA-transfected L-02 cells, analysis by cell flow cytometry revealed that treatment with MFA further blocked ROS elevation triggered by ethanol (Figs. 5B and 6B). MTT assay demonstrated that when the L-02 cells were exposed to ethanol following treatment with MFA, the decrease in cellular viability induced by ethanol was suppressed, indicating that MFA protected the L-02 cells from ethanol-induced cell toxicity (Figs. 5C and 6C). Taken together, these results suggested that signaling driven by NOX4/p22 $2^{\text {phox }}$ was the major mechanism underlying the anti-oxidative stress activity of MFA against the generation of ROS triggered by ethanol in L-02 cells. These results suggested that MFA protected hepatocytes from ethanolinduced apoptosis through the inactivation of the NOX4/ROS/ p38/JNK pathway.

\section{Discussion}

As the pharmacological options available for the therapy of liver diseases are limited, proof of effective hepatic protective agents from natural sources is important. Therefore, it is significant to evaluate plant extracts that can help to restore liver function. MFA is a monomer isolated from Securidaca inappendiculata Hassk., which possesses positive antiviral activity via the specific combination with GP120 to prevent the virus reverse transcriptase from interaction with the lymphocytes (21). The present study surveyed the hepatoprotective activity of MFA using an ethanol-exposed L-02 cell model. The results demonstrated that treatment with MFA significantly reduce elevated ROS levels and reversed ethanol-induced L-02 cell apoptosis, indicating that MFA was responsible for a hepatoprotective effect. 
$\mathbf{A}$
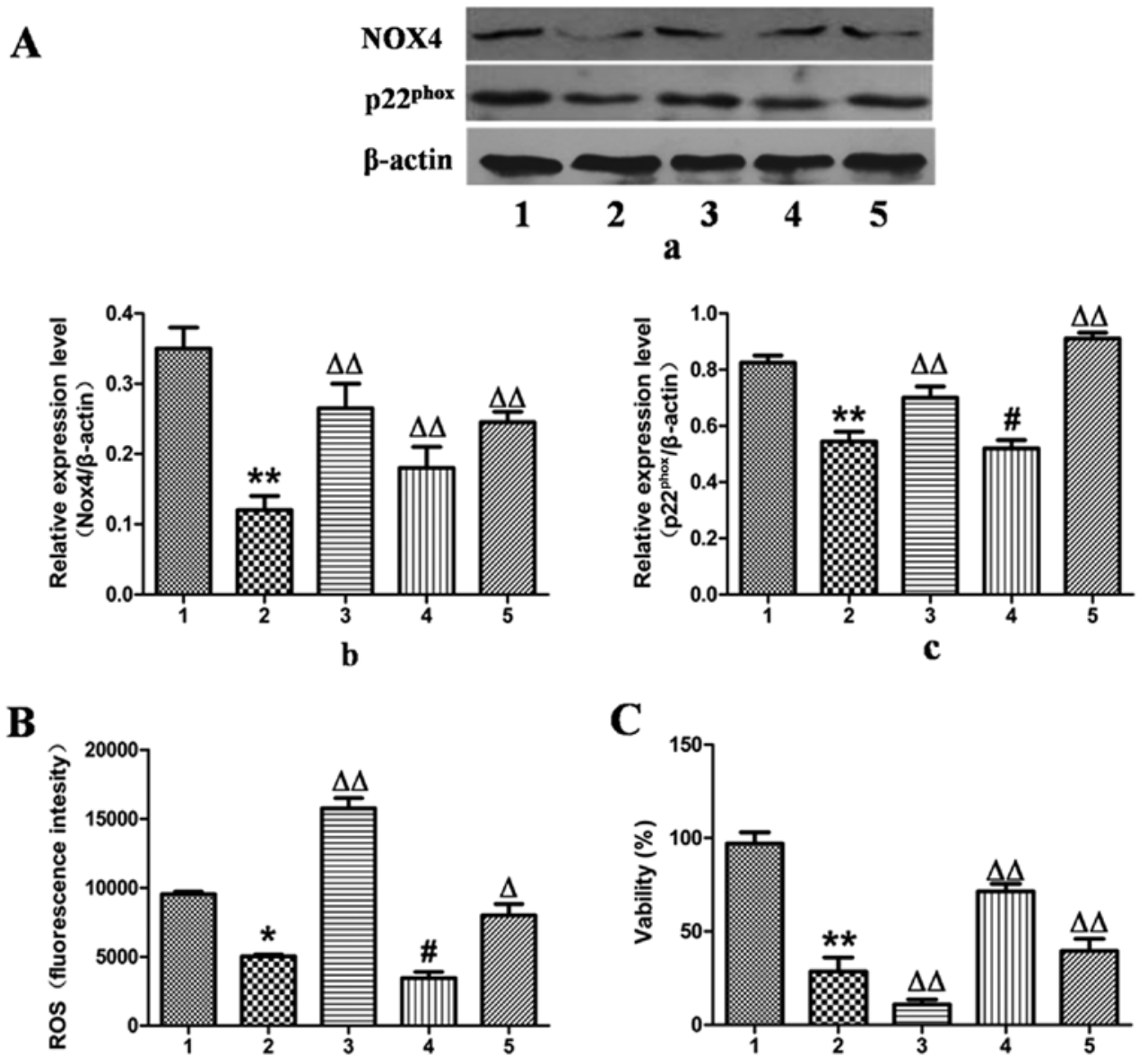

Figure 6. Effect of methyl ferulic acid (MFA) on ethanol-induced reactive oxygen species (ROS) generation in L-02 cells transfected with NOX4-siRNA. Following transfection with NOX4-siRNA for $24 \mathrm{~h}$, the L-02 cells were treated as designated. (A) Representative images and protein expression levels of p22 phox were normalized to $\beta$-actin. (B) Measurement of intracellular ROS levels using DCFH-DA in various groups. (C) Cell viability was measured by MTT assay in NOX4-siRNA-transfected L-02 cells. Data are expressed as the means $\pm \mathrm{SD}, \mathrm{n}=3 .{ }^{*} \mathrm{P}<0.05$ and ${ }^{* *} \mathrm{P}<0.01$ vs. the control group; ${ }^{\wedge} \mathrm{P}<0.05$ and ${ }^{\triangle} \triangle \mathrm{P}<0.01$ vs. the ethanol group; ${ }^{~} \mathrm{P}<0.05$ vs. the control group. Lanes and bars are labeled as follows: 1, control; 2, siRNA-transfected group; 3 , siRNA-transfected group exposed to ethanol; 4, siRNA-transfected group treated with MFA; 5, siRNA-transfected group exposed to ethanol and treated with MFA.

The present study explored the possible effects of MFA on the viability and apoptosis induced by ethanol. The results from in vitro experiments revealed that MFA attenuated the ethanol-induced inhibition of the viability and apoptosis of L-02 cells. Previous studies have reported the use of MFA in the therapy of acute or chronic hepatitis and that it demonstrated some inhibitory effect on HBsAg $(16,17)$. Its analog improved antioxidant activity and anti-lipid peroxidation that protects cells against oxidative stress. Ferulic acid (FA) alleviated the oxidative stress and decreased cell apoptosis induced by high glucose in hepatocytes (22). Whether MFA inhibited the apoptosis induced by ethanol in L-02 cells remained to be elucidated. In this study, the results from flow cytometry demonstrated that MFA inhibited the ethanol-induced apoptosis of L-02 cells, suggesting that its antioxidant properties may contribute to its anti-apoptotic activity.

Additionally, the present study identified that culturing the L-02 cells with MFA $(25 \mu \mathrm{M})$ reduced apoptosis and ROS production (Figs. 2A and 5B). Maruf et al (23) examined FA and demonstrated that it can protect isolated rat hepatocytes against glyoxal- or methylglyoxal-induced cytotoxicity and oxidative stress. FA attenuated hepatocyte apoptosis which induced ischemia/reperfusion (I/R) via the inhibition of JNK activation (24). In addition, the results of the study by
Urias-Lugo et al (25) demonstrated that culturing HepG2 cells and primary hepatocytes with phenolic acids exerted an antiproliferative effect. FA may cause cell cycle arrest in PC-3 cells and leads to the apoptosis of LNCaP cells (26). MFA treatment at a concentration of $25 \mu \mathrm{M}$ inhibited the proliferation induced by TGF- $\beta$ in HSC-LX- 2 cells (27). These various results indicate that MFA may exert differential effects in different cell types; that is, MFA can be either cytoprotective or cytotoxic depending on the cell type.

In this study, when the L- 02 cells were incubated with ethanol at the concentration of $400 \mathrm{mM}$, ROS generation was increased with the time of incubation. As one of 6 homologues of transmembrane NADPH oxidase, NOX4 has been identified to be involved in ROS generation and highly expressed in the liver (28). In the liver, NOX4 is expressed in hepatocytes and is upregulated by ethanol or TGF- $\beta$ in vitro as well as in vivo. It is activated in HSCs and, to a small extent, in sinusoidal endothelial cells, although Chuffer cells do not express it $(29,30)$. Furthermore, NOX4 and p22 $2^{\text {phox }}$ are upregulated in patients exposed to ethanol (31). In this study, the pronounced expression of NOX4 was identified by western blot analysis and was confirmed by RT-PCR in L-02 cells. The results of the present study demonstrated that the mRNA levels of NOX4 and $\mathrm{p} 22^{\text {phox }}$ were increased when the L- 02 cells were incubated 
with ethanol (Fig. 4B), demonstrating that NOX4 and p22 $2^{\text {phox }}$ are required when activating NOX4 on the membrane. The data from western blot analysis of NOX4 further substantiated this at the protein level.

In the NOX4 overexpression and NOX4 siRNA knockdown experiments, it was identified that NOX4 upregulation caused the upregulation of its regulatory subunit, $\mathrm{p} 22^{\text {phox }}$ and, simultaneously, NOX4 downregulation caused the downregulation of $\mathrm{p} 22^{\mathrm{phox}}$ in $\mathrm{L}-02$ cells exposed to ethanol. The results of the present study support those of previous findings in that SK-Hep1 cells and alveolar macrophage mRNA levels of NOX 4 and p $22^{\text {phox }}$ increased when the cells were incubated with ethanol (13), which also demonstrated that both are required to activate NOX4 on the membrane. However, the mechanisms behind the interaction between NOX4 and $\mathrm{p} 22^{\text {phox }}$ remain to be elucidated; further studies are warranted to elucidate these mechanisms.

Based on the results of the present study, the release of ROS was, at least in part, mediated by NOX4 in the ethanol-exposed L- 02 cells. The overproduction of ROS is one of the main causes of increasing oxidative stress and triggering apoptosis $(32,33)$. The results of the present study suggested that ROS generation mediated by NOX4 on the hepatocyte membrane was a trigger of apoptosis in ethanol-exposed L-02 cells.

Compared with the ethanol-exposed group, MFA significantly decreased the elevated NOX4 mRNA and protein expression levels induced by ethanol in varying degrees (Figs. 4-6). This result was consistent with the results obtained from the ROS and apoptosis experiments, in that ROS generation and the apoptosis of L-02 cells corresponded with the changes in NOX4 expression. Further investigations into the underlying mechanisms of the anti-apoptotic effects of MFA are required.

Recently, various studies have identified that ROS may play a critical role in the induction of apoptosis $(23,34)$. Oxidative stress can be induced by abnormal ROS release or their constant generation and this is related to apoptosis and other biological events (35). ROS are one of the pivotal regulators of cell signal transduction and are associated with apoptosis, senescence and proliferation (28). A number of drug candidates fulfil a cytotoxic role through the production of ROS as a critical regulator. Studies have demonstrated that the metabolism of ethanol in liver cells can induce ROS production $(32,36)$. It has been demonstrated that ethanol-mediated ROS production can cause alterations in cellular morphology and functions and/or eventually lead to apoptosis $(35,36)$. For example, the dysfunction of the mitochondria induced by excessive ROS production results in apoptosis (37). ROS are also known to be activators of the MAPK signaling pathway (38). The results of the present study demonstrated that the sustained phosphorylation of p38 MAPK and JNK was caused by ROS production following exposure to ethanol (Fig. 4A and B). The suppression of ROS generation by MFA treatment alleviated the effects of ethanol on JNK and p38 MAPK phosphorylation, suggesting that ethanol induced the generation of ROS, which consequently transformed phosphorylated p38 MAPK and JNK, and caused the activation of p38 MAPK and JNK, finally leading to the translocation of Bax to the mitochondria.

Ethanol induced the inhibition of cell growth and triggered the apoptosis of L-02 cells; however, this process was effectively blocked by MFA treatment. Ethanol-induced apoptosis occurs via a decline in Bcl-2 protein synthesis and the transfer of Bax to the mitochondria (39). The present study demonstrated that ROS, JNK, p38 MAPK and Bax participated in the ethanol-triggered apoptotic pathway. In line with this finding, ROS may serve as an upstream signal mediator of the p38 MAPK and JNK signaling pathways in L-02 cells treated with ethanol (Fig. 3E). There is evidence from a previous study to indicate that ROS can aggravate apoptosis induced by a variety of stimuli (40).

One of the important factors for the apoptosis induced by the mitochondrial pathway is the collapse of mitochondrial membrane potential, which leads to the release of cytochrome $c$ and the activation of caspase-9. This event is mediated by anti-apoptotic proteins of the Bcl-2 family. Particularly, the transfer of Bax to the mitochondria leads to the alteration of mitochondrial membrane potential and Bax plays a critical role in triggering apoptosis in response to various stimuli (41). Although Bax is mainly located in the cytoplasm, when stimulated, it can move closer to the mitochondrial membrane (42). When Bax converges onto the mitochondria, combining with other pro-apoptotic Bcl-2 family members, it induces the release of cytochrome $c$ through the pore channels formed in the outer membrane of the mitochondria by oligomerization or by other channels (43-45). Phosphorylation of JNK and p38 MAPK activates Bax, either alone or in combination (46). In the present study, MFA inhibited induction of caspase-3 activation by ethanol in L- 02 cells. The increased ratio of $\mathrm{Bax}$ and $\mathrm{Bcl}-2$ can alter the mitochondrial membrane potential and lead to the release of cytochrome $c$, and then further activate caspase- 3 to trigger apoptosis $(47,48)$. As shown in Fig. 2B and C, exposure to ethanol upregulated the mRNA expression of $\mathrm{Bax}$ and $\mathrm{Bcl}-2$, but also increased the ratio of $\mathrm{Bax}$ to Bcl-2 both at the mRNA and protein level; these effects of ethanol were antagonized by MFA. The results indicated that apoptosis plays an important role in ethanol-induced L- 02 cell injury and its effect on the mitochondrial pathway. The results of the present study seem to suggest that exposure to ethanol leads to mitochondrial damage and the caspase-dependent apoptosis of L-02 cells.

Although originally identified as an antioxidant, MFA is currently believed to act through different mechanisms in different biological responses. However, the mechanisms through which MFA inhibits ethanol-induced L-02 cell apoptosis are unclear. The present study demonstrated that MFA decreased apoptosis by inhibiting the activation of the p38 MAPK and JNK pathways in L-02 cells. The data identified that MFA treatment caused the persistent inactivation of p38 MAPK and JNK in L-02 cells (Fig. 4C). The signaling proteins in the MAPK family promote a variety of biological reactions in cells and p38 MAPK and JNK play a key role in the signal transduction of apoptosis (49). Since the release of cytochrome $c$ from damaged mitochondria is a key step in the activation of caspases, the finding that JNK and p38 MAPK activities are essential for caspase activation indicates that JNK and p38 MAPK can regulate some of the other mitochondrial-related factors (e.g., Bax). In L-02 cells, MFA treatment caused the downregulation of JNK and p-38 phosphorylation (Fig. 4C), which is in part similar to the results obtained in I/R-induced hepatocytes treated with 
FA (24). Briefly, MFA attenuated the apoptosis of L-02 cells induced by ethanol via the inhibition of the ROS-dependent JNK/p38 MAPK signaling pathway. However, further studies are required to elucidate the mechanisms through which MFA inhibits NOX4 to reduce ROS generation.

In brief, the results of the present study demonstrated that MFA suppressed ethanol-triggered oxidative stress in L-02 cells by inhibiting ROS production and the upregulation of GSH-PX, CAT and SOD. The role of MFA in modulating MAPK phosphorylation, and its established antioxidant effect, suggest that this compound may prove to be a good candidate for use in the treatment of ALD.

In conclusion, the present study demonstrated for the first time, to the best of the authors' knowledge, that MFA exerts beneficial effects against the ethanol-induced lack of viability and apoptosis by inhibiting ROS-dependent JNK, the p38 MAPK signaling pathway and the Bcl-2/Bax signaling pathway in L-02 cells. MFA treatment led to the upregulation of p-JNK, p-p38 MAPK and Bax, and the downregulation of Bcl-2 and cleaved caspase-3. A new understanding of the role of MFA was developed in that it attenuated the apoptosis of L-02 cells induced by ethanol by inhibiting the activation of the MAPK signaling pathway. In the present study, the L-02 cells used in the in vitro experiments were normal human hepatocytes. Whether MFA treatment can inhibit the apoptosis of hepatocytes in vivo requires further investigation. The present study provides a novel theoretical basis for the possible use of MFA in the treatment of liver injury.

\section{Acknowledgements}

Not applicable.

\section{Funding}

This study was funded by The National Natural Science Foundation of China (grant nos. 81360497 and 81760669).

\section{Availability of data and materials}

All data generated or analyzed during this study are included in this published article.

\section{Authors' contributions}

LL and YZ wrote manuscript, performed experiments and analyzed data; CY, CL, LC, HW and MZR performed experiments and analyzed data. ZM, CY, LL, HW and YL analyzed the data. ZM and YL contributed to the discussions and critically edited the manuscript. All authors have reviewed and approved the manuscript. All authors are responsible for the integrity of the data.

\section{Ethics approval and consent to participate}

Not applicable.

\section{Consent for publication}

Not applicable.

\section{Competing interests}

The authors declare that they have no competing interests.

\section{References}

1. Duncan C: Rethinking excessive habits and addictive behaviors. Alcohol Alcohol 52: 128-129, 2017.

2. Owens RE, Snyder HS, Twilla JD and Satapathy SK: Pharmacologic treatment of alcoholic hepatitis: Examining outcomes based on disease severity stratification. J Clin Exp Hepatol 6: 275-281, 2016.

3. Kim JW, Yang H, Kim HW, Kim HP and Sung SH: Lignans from Opuntia ficus-indica seeds protect rat primary hepatocytes and HepG2 cells against ethanol-induced oxidative stress. Biosci Biotechnol Biochem 81: 181-183, 2017.

4. Sugimoto K and Takei Y: Pathogenesis of alcoholic liver disease. Hepatol Res 47: 70-79, 2017.

5. Magdaleno F, Blajszczak CC and Nieto N: Key events participating in the pathogenesis of alcoholic liver disease. Biomolecules 7: E9, 2017.

6. Sinha K, Das J, Pal PB and Sil PC: Oxidative stress: The mitochondria-dependent and mitochondria-independent pathways of apoptosis. Arch Toxicol 87: 1157-1180, 2013.

7. Simplicio JA, do Vale GT, Gonzaga NA, Leite LN, Hipólito UV, Pereira CA, Tostes RC and Tirapelli CR: Reactive oxygen species derived from $\mathrm{NAD}(\mathrm{P}) \mathrm{H}$ oxidase play a role on ethanol-induced hypertension and endothelial dysfunction in rat resistance arteries. J Physiol Biochem 73: 5-16, 2017.

8. Zhu H, Jia Z, Misra H and Li YR: Oxidative stress and redox signaling mechanisms of alcoholic liver disease: Updated experimental and clinical evidence. J Dig Dis 13: 133-142, 2012.

9. Zwolak A, Surdacka A and Daniluk J: Bcl-2 and Fas expression in peripheral blood leukocytes of patients with alcoholic and autoimmune liver disorders. Hum Exp Toxicol 35: 799-807, 2016.

10. Paik YH, Kim J, Aoyama T, De Minicis S, Bataller R, Brenner DA: Role of NADPH oxidases in liver fibrosis. Antioxid Redox Signal 20: 2854-2872, 2014.

11. Pan JH, Lim Y, Kim JH, Heo W, Lee KY, Shin HJ, Kim JK, Lee JH, Kim YJ: Root bark of Ulmus davidiana var. japonica restrains acute alcohol-induced hepatic steatosis onset in mice by inhibiting ROS accumulation. PLoS One 12: e0188381, 2017.

12. Venugopal SK, Chen J, Zhang Y, Clemens D, Follenzi A and Zern MA: Role of MAPK phosphatase-1 in sustained activation of JNK during ethanol-induced apoptosis in hepatocyte-like VL-17A cells. J Biol Chem 282: 31900-31908, 2007.

13. Morio Y, Tsuji M, Inagaki M, Nakagawa M, Asaka Y, Oyamada H, Furuya K and Oguchi K: Ethanol-induced apoptosis in human liver adenocarcinoma cells (SK-Hep1): Fas- and mitochondriamediated pathways and interaction with MAPK signaling system. Toxicol In Vitro 27: 1820-1829, 2013.

14. Yao X, Bai Q, Yan D, Li G, Lü C and Xu H: Solanesol protects human hepatic L02 cells from ethanol-induced oxidative injury via upregulation of HO-1 and Hsp70. Toxicol In Vitro 29: 600-608, 2015.

15. Guo X, Cui R, Zhao J, Mo R, Peng L and Yan M: Corosolic acid protects hepatocytes against ethanol-induced damage by modulating mitogen-activated protein kinases and activating autophagy. Eur J Pharmacol 791: 578-588, 2016.

16. Li L, Li YW and Tang AC: The inhibitory effect of methyl ferulic acid on HBsAg and HBeAg in HepG2.2.15 cell. Pharmacol Clin Chin Materia Med 27: 14-16, 2011.

17. Zheng MS and Li W: Inhibitory effect of 400 kinds of Chinese herbal medicine on HBsAg. Chin J Integr Tradit West Med Liver Diseas 6: 30-31, 1991.

18. Li C, Li L, Yang CF, Zhong YJ, Wu D, Shi L, Chen L and Li YW: Hepatoprotective effects of Methyl ferulic acid on alcoholinduced liver oxidative injury in mice by inhibiting the NOX4/ ROS-MAPK pathway. Biochem Biophys Res Commun 493: 277-285, 2017.

19. Müller TE, Nunes SZ, Silveira A, Loro VL and Rosemberg DB: Repeated ethanol exposure alters social behavior and oxidative stress parameters of zebrafish. Prog Neuropsychopharmacol Biol Psychiatry 79: 105-111, 2017.

20. Grasselli E, Compalati AD, Voci A, Vecchione G, Ragazzoni M, Gallo G, Borro P, Sumberaz A, Testino G and Vergani L: Altered oxidative stress/antioxidant status in blood of alcoholic subjects is associated with alcoholic liver disease. Drug Alcohol Depend 143: 112-119, 2014. 
21. Yang XD, Xu LZ and Yang SL: Advances in studies on medicinal plants of Securidaca. Chin Tradit Herbal Drugs 31: 392-393, 2000.

22. Song Y, Wen L, Sun J, Bai W, Jiao R, Hu Y, Peng X, He Y and Ou S: Cytoprotective mechanism of ferulic acid against high glucose-induced oxidative stress in cardiomyocytes and hepatocytes. Food Nutr Res 60: 30323-30331, 2016.

23. Maruf AA, Lip H, Wong H and O'Brien PJ: Protective effects of ferulic acid and related polyphenols against glyoxal- or methylglyoxal-induced cytotoxicity and oxidative stress in isolated rat hepatocytes. Chem Biol Interact 234: 96-104, 2015.

24. Kim HY and Lee SM: Ferulic acid attenuates ischemia/ reperfusion-induced hepatocyte apoptosis via inhibition of JNK activation. Eur J Pharm Sci 45: 708-715, 2012.

25. Urias-Lugo DA, Heredia JB, Muy-Rangel MD, Valdez-Torres JB Serna-Saldívar SO and Gutiérrez-Uribe JA: Anthocyanins and phenolic acids of hybrid and native blue maize (Zea mays L.) extracts and their antiproliferative activity in mammary (MCF7), liver (HepG2), colon (Caco2 and HT29) and prostate (PC3) cancer cells. Plant Foods Hum Nutr 70: 193-199, 2015.

26. Eroğlu C, Seçme M, Bağc1 G and Dodurga Y: Assessment of the anticancer mechanism of ferulic acid via cell cycle and apoptotic pathways in human prostate cancer cell lines. Tumour Biol 36 : 9437-9446, 2015.

27. Xiong M, LI Y, LI L, Yang C and Zhong Y: Inhibitory effect of methy-ferulic acid on proliferation and activation of TGF- $\beta 1$-induced human hepatic stellate cells. Shandong Pharmaceuticals 56: 1-4, 2016.

28. Kleniewska P, Piechota A, Skibska B and Gorąca A: The NADPH oxidase family and its inhibitors. Arch Immunol Ther Exp (Warsz) 60: 277-294, 2012.

29. Ceni E, Mello T and Galli A: Pathogenesis of alcoholic liver disease: Role of oxidative metabolism. World J Gastroenterol 20: 17756-17772, 2014.

30. Bettaieb A, Jiang JX, Sasaki Y, Chao TI, Kiss Z, Chen X, Tian J, Katsuyama M, Yabe-Nishimura C, Xi Y, et al: Hepatocyte nicotinamide adenine dinucleotide phosphate reduced oxidase 4 regulates stress signaling, fibrosis, and insulin sensitivity during development of steatohepatitis in mice. Gastroenterology 149 468-80.e10, 2015.

31. Colmenero J, Bataller R, Sancho-Bru P, Bellot P, Miquel R, Moreno M, Jares P, Bosch J, Arroyo V, Caballería J, et al: Hepatic expression of candidate genes in patients with alcoholic hepatitis: Correlation with disease severity. Gastroenterology 132: 687-697, 2007.

32. Yeligar SM, Harris FL, Hart CM and Brown LA: Glutathione attenuates ethanol-induced alveolar macrophage oxidative stress and dysfunction by downregulating NADPH oxidases. Am J Physiol Lung Cell Mol Physiol 306: L429-L441, 2014.

33. Valero T: Mitochondrial biogenesis: Pharmacological approaches Curr Pharm Des 20: 5507-5509, 2014

34. Zhu Y, Jiang Y, Shi L, Du L, Xu X, Wang E, Sun Y, Guo X, Zou B, Wang $\mathrm{H}$, et al: 7-O-Geranylquercetin induces apoptosis in gastric cancer cells via ROS-MAPK mediated mitochondrial signaling pathway activation. Biomed Pharmacother 87: 527-538, 2017.

35. Ma L, Dong JX, Wu C, Li XY, Chen J, Zhang H and Liu Y: Spectroscopic, polarographic, and microcalorimetric studies on mitochondrial dysfunction induced by ethanol. J Membr Biol 250: 195-204, 2017.

36. Chen LY, Chen Q, Zhu XJ, Kong DS, Wu L, Shao JJ and Zheng SZ: Diallyl trisulfide protects against ethanol-induced oxidative stress and apoptosis via a hydrogen sulfide-mediated mechanism. Int Immunopharmacol 36: 23-30, 2016.
37. Hoyt LR, Randall MJ, Ather JL, DePuccio DP, Landry CC, Qian X, Janssen-Heininger YM, van der Vliet A, Dixon AE, Amiel E, et al: Mitochondrial ROS induced by chronic ethanol exposure promote hyper-activation of the NLRP3 inflammasome. Redox Biol 12: 883-896, 2017.

38. Zhang C, Jia X, Bao J, Chen S, Wang K, Zhang Y, Li P, Wan JB, $\mathrm{Su} \mathrm{H}$, Wang Y, et al: Polyphyllin VII induces apoptosis in HepG2 cells through ROS-mediated mitochondrial dysfunction and MAPK pathways. BMC Complement Altern Med 16: 58-69, 2016.

39. Bonet-Ponce L, Saez-Atienzar S, da Casa C, Flores-Bellver M, Barcia JM, Sancho-Pelluz J, Romero FJ, Jordan J and Galindo MF: On the mechanism underlying ethanol-induced mitochondrial dynamic disruption and autophagy response. Biochim Biophys Acta 1852: 1400-1409, 2015.

40. Yang L, Wu L, Du S, Hu Y, Fan Y and Ma J: 1,25(OH)2D3 inhibits high glucose-induced apoptosis and ROS production in human peritoneal mesothelial cells via the MAPK/P38 pathway. Mol Med Rep 14: 839-844, 2016.

41. Andreu-Fernández V, Sancho M, Genovés A, Lucendo E, Todt F, Lauterwasser J, Funk K, Jahreis G, Pérez-Payá E, Mingarro I, et al: Bax transmembrane domain interacts with prosurvival Bcl-2 proteins in biological membranes. Proc Natl Acad Sci USA 114: 310-315, 2017

42. Kim JA, Kim JC, Min JS, Kang I, Oh J and Ahn JK: HSV-1 ICP27 induces apoptosis by promoting Bax translocation to mitochondria through interacting with $14-3-3 \theta$. BMB Rep 50: 257-262, 2017.

43. Reshi L, Wang HV, Hui CF, Su YC and Hong JR: Anti-apoptotic genes Bcl-2 and Bcl-xL overexpression can block iridovirus serine/threonine kinase-induced $\mathrm{Bax} /$ mitochondria-mediated cell death in GF-1 cells. Fish Shellfish Immunol 61: 120-129, 2017.

44. Salvador-Gallego R, Mund M, Cosentino K, Schneider J, Unsay J, Schraermeyer U, Engelhardt J, Ries J and García-Sáez AJ: Bax assembly into rings and arcs in apoptotic mitochondria is linked to membrane pores. EMBO J 35: 389-401, 2016.

45. Gómez-Crisóstomo NP, López-Marure R, Zapata E, Zazueta C and Martínez-Abundis E: Bax induces cytochrome $c$ release by multiple mechanisms in mitochondria from MCF7 cells. J Bioenerg Biomembr 45: 441-448, 2013.

46. Tsai MH, Liu JF, Chiang YC, Hu SC, Hsu LF, Lin YC, Lin ZC, Lee HC, Chen MC, Huang CL, et al: Artocarpin, an isoprenyl flavonoid, induces p53-dependent or independent apoptosis via ROS-mediated MAPKs and Akt activation in non-small cell lung cancer cells. Oncotarget 8: 28342-28358, 2017.

47. Yang Y, Zong M, Xu W, Zhang Y, Wang B, Yang M and Tao L: Natural pyrethrins induces apoptosis in human hepatocyte cells via Bax- and Bcl-2-mediated mitochondrial pathway. Chem Biol Interact 262: 38-45, 2017

48. Yan X, Jiang Z, Bi L, Yang Y and Chen W: Salvianolic acid A attenuates TNF- $\alpha$ - and D-GalN-induced ER stress-mediated and mitochondrial-dependent apoptosis by modulating Bax/Bcl-2 ratio and calcium release in hepatocyte LO2 cells. Naunyn Schmiedebergs Arch Pharmacol 388: 817-830, 2015.

49. Chuang WL, Lin PY, Lin HC and Chen YL: The Apoptotic effect of ursolic acid on SK-Hep-1 cells is regulated by the PI3K/Akt, p38 and JNK MAPK signaling pathways. Molecules 21: 460-470, 2016. 